\title{
PROBLEMS OF UKRAINE'S INTEGRATION INTO THE EUROPEAN UNION
}

\author{
Viktoriia STOIKA \\ University of Science and Technology, Faculty of Management, Bydgoszcz; viktoriia.stoika@utp.edu.pl, \\ ORCID: 0000-0002-6356-890X
}

\begin{abstract}
Purpose: The purpose of the article is to establish the place of Ukraine on the process of European integration and the identification of obstacles to full membership in the European Union.
\end{abstract}

Design/methodology/approach: The methodological and theoretical basis of the article is the fundamental provisions of economic theory, the works of scientists and economists in the field of international economic relations and integration.

Findings: The article explores the problems of Ukraine's integration into the EU. The study analyzed the attitude of Ukrainians towards European integration, identified the main arguments for and against accession to the EU countries, as well as the main internal and external threats of the integration process. It has been determined that in recent years the proportion of the population that has supported Ukraine's accession to the EU has significantly increased. From the integration into the EU, Ukrainians primarily expect to expand the space of their own capabilities and the country's internal development in accordance with modern world trends. It is concluded that the population considers a high level of corruption in the country, problems in the Donbass and the inefficiency of public administration as the main obstacles to this process. Most residents of Ukraine consider it necessary to implement European reforms, but the consequence of their implementation has identified significant problems in terms of their real social effect. It is determined that Ukraine in some macroeconomic indicators lags significantly behind the EU countries, continues to lose its position in the global ranking of countries in terms of economic competitiveness, and remains one of the poorest countries in Europe. A significant problem for the development of Ukraine is the labor migration of the population and, in particular, the increase in the number of illegal migrants - Ukrainians in Europe. The main achievements in the implementation of the Association Agreement between Ukraine and the EU are analyzed and the main threats to the further European integration are identified. It is concluded that Ukraine needs to develop its own "action plan" for the possibility of realizing national interests, taking into account the interests of the parties involved in the integration process.

Originality/value: The mood of Ukrainian society, the current position of the state, the main obstacles and priorities that Ukraine faces on the way to the EU have been analysed in detail.

Keywords: integration, European integration, Ukraine, EU, reforms.

Category of the paper: research paper. 


\section{Introduction}

The European integration aspirations of the Ukrainian people, primarily their desire to establish close and full-fledged cooperation with other European nations, are natural and understandable for many reasons. Indeed, on the one hand, the Ukrainian people are an integral part of the European civilization community and a reliable guardian of its eastern borders. On the other hand, the Ukrainian people have passed the ordeals in its centuries-old history. The Ukrainian people longer among other European peoples was forcibly removed from the family of free European peoples in the 20th century as a result of Russian ("Soviet") occupation. In this regard the fact that it was the Ukrainians who were the first in history to lay their lives under the flags of the European Union, defending their right to a free European future in January-February 2014 (Revolution of Dignity), is distinctive.

In February 2019, the Constitution of Ukraine established a strategic course for full membership in the EU and NATO. This was done to ensure the irreversibility of the path that the Ukrainian people took. The civilization choice of the young Ukrainian state was European integration, which should carry out deep systemic transformations in the state, the establishment of democracy and the rule of law, modernization of the political system to protect human rights, the formation of a coherent democratic identity of Ukrainian society, the spread of modern technologies of political and economic management, approval of Ukraine as a competitive and investment attractive participant in the global economy.

Strengthening and accelerating international integration processes poses a number of questions and problems for the Ukrainian economy. However, given the development of economic relations between Ukraine and the EU countries, the study of the integration processes of Ukraine requires constant research.

European integration and the place in this process of Ukraine is an extremely complicated issue. A number of scientific works of European politicians and scientists are devoted to the problems of integration processes and the development of the EU itself at the present stage. Among them, it is worth highlighting the publications of Stiglitz J. (Stiglitz, 2016); Soros G. and Schmitz G. (Soros, and Schmitz, 2016); Berend I. (Berend, 2017); Chalmers D., Jachtenfuchs M. and Joerges C. (Chalmers et al., 2016); Archick K. (Archick, 2017); Bassot E. (Bassot, 2017); Emmer F. and Petrovi S. (Emmer, and Petrovi, 2014); Catherine E. de Vries, (Catherine de Vries, 2018); Chaputovych I. (Chaputovych, 2016), Zięba R. (Zięba, 2017), Zhukrovska K. (Zhukrovska, 2017). Some aspects of Ukraine's European integration problems were analyzed by such researchers as Sidenko V. (Sidenko, 2018), Shynkar V.A., Roshko S.M. and Yatsko G.V. (Shynkar et al., 2017), Osipova L. (Osipova, 2015), Stepanenko V.O. and Stepanenko N.O. (Stepanenko, V., and Stepanenko, N., 2018), Pysin V.M. and Echina L.V. (Pysin, and Echina, 2017), Obozna A.O. and Klimova M.V. (Obozna, and Klimova, 2017). 
The reality of Ukraine's European integration requires an in-depth analysis and comparison of the legislative, legal, economic, social and other aspects of our country with EU partners, as well as an assessment of their compliance with the euro integration principles. An objective analysis of such a correspondence is equally relevant for Ukraine and the European Community, since even a simple physical increase in the EU system complicates it, requiring new additional regulators, each of which has limited capabilities.

The purpose of the article is to establish the place of Ukraine on the process of European integration and the identification of obstacles to full membership in the European Union. The set goal made it necessary to study the mood of Ukrainian society, the current position of the state, the main obstacles and priorities that Ukraine faces on the way to the EU.

\section{Methods}

The methodological and theoretical basis of the article is the fundamental provisions of economic theory, the works of scientists and economists in the field of international economic relations and integration. The statistical data for the analysis of the public's attitude towards European integration in Ukraine was provided by the data of a nationwide sociological study conducted in May-June 2019 by the Center of Strategic Development of Areas.

In the course of the study, dialectical and general scientific methods of cognition were used: theoretical generalization, analysis and synthesis - to justify the need for European integration; statistical analysis - to analyze trends and characteristics of economic development of Ukraine; comparisons - to identify trends in the development of the national economy; system analysis - to determine the directions and prospects of Ukraine's inclusion in the EU.

\section{Results}

In June 1993, the European Council at its meeting in Copenhagen recognized the right of the countries of Central and Eastern Europe to join the EU after they fulfill the requirements according to three criteria:

- Political: stability of institutions guaranteeing democracy, rule of law, respect for human rights and protection of minority rights;

- Economic: an efficient market economy;

- Membership: obligations arising from the fact of joining the EU, in particular the recognition of its political, economic and monetary goals. 
An effective integration is possible only in countries that are geographically close, have a political interest in unification, and approximately the same level of economic development.

In recent years, Ukrainian society has changed significantly, in particular, changes have occurred in the spiritual, cultural and political values that have clearly evolved. At the same time, the issue of confronting moral values in Ukrainian society is becoming increasingly relevant. European values - democracy, tolerance, human rights - are opposed by the Russian worldview. In modern conditions, the values of Ukrainian society have caused Ukraine to move away from Russia towards the EU. Such a conclusion is reflected in the results of a nationwide sociological study of public attitudes towards Ukraine's integration into the EU, conducted in May-June 2019. The data show that $69 \%$ of the population supports Ukraine's accession to the EU. At the same time, the number of Ukrainians who support the European integration rate increased by $27 \%$ compared to 2012 (Figure 1):

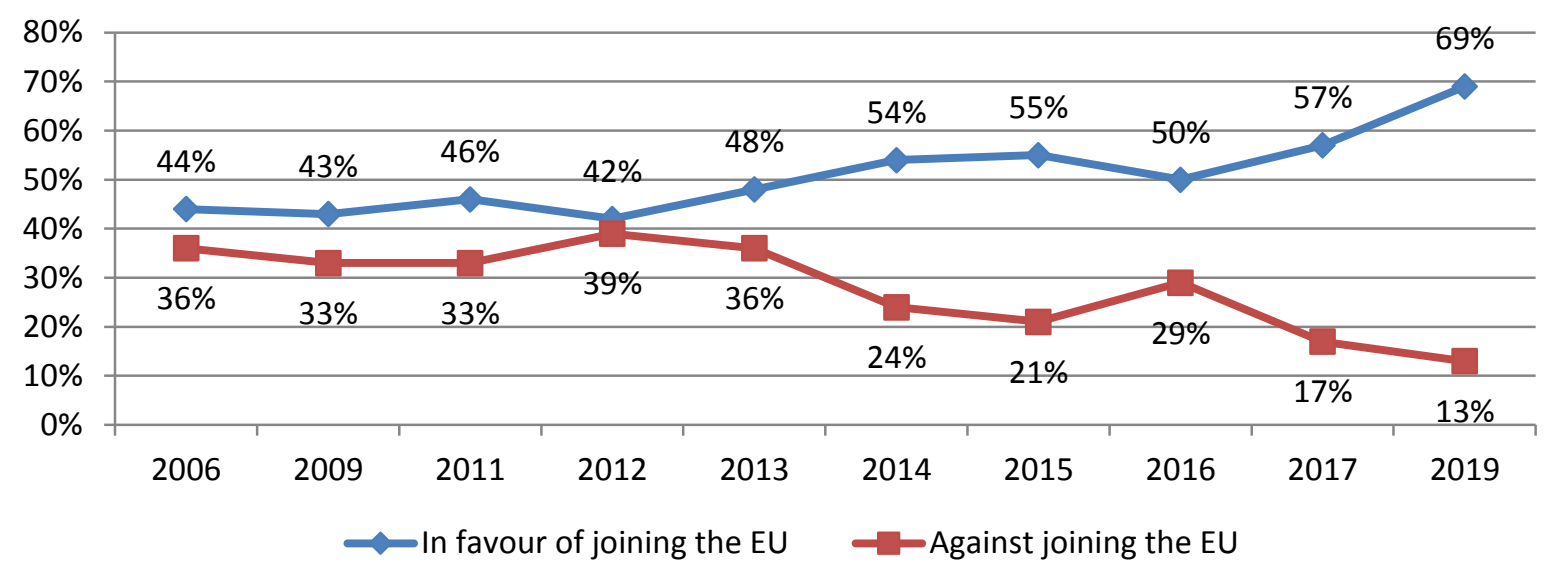

Figure 1. The attitude of the Ukrainians regarding the entry of Ukraine into the EU. Adapted from: Public attitude towards Ukraine's integration into the EU. Results of a nationwide sociological survey, 2019 year.

It should be noted that such an attitude of the population of Ukraine is uneven. In particular, while among the residents of the western part of the country, accession to the EU supports $81 \%$, and against $6 \%$, in the Donbas $48 \%$ and $19 \%$, respectively. In general, $63 \%$ of residents confide in the European Union as a strategic partner of Ukraine, and $64 \%$ of the population believe that the main direction of foreign policy should be establishing relations with EU countries (Figure 2). 


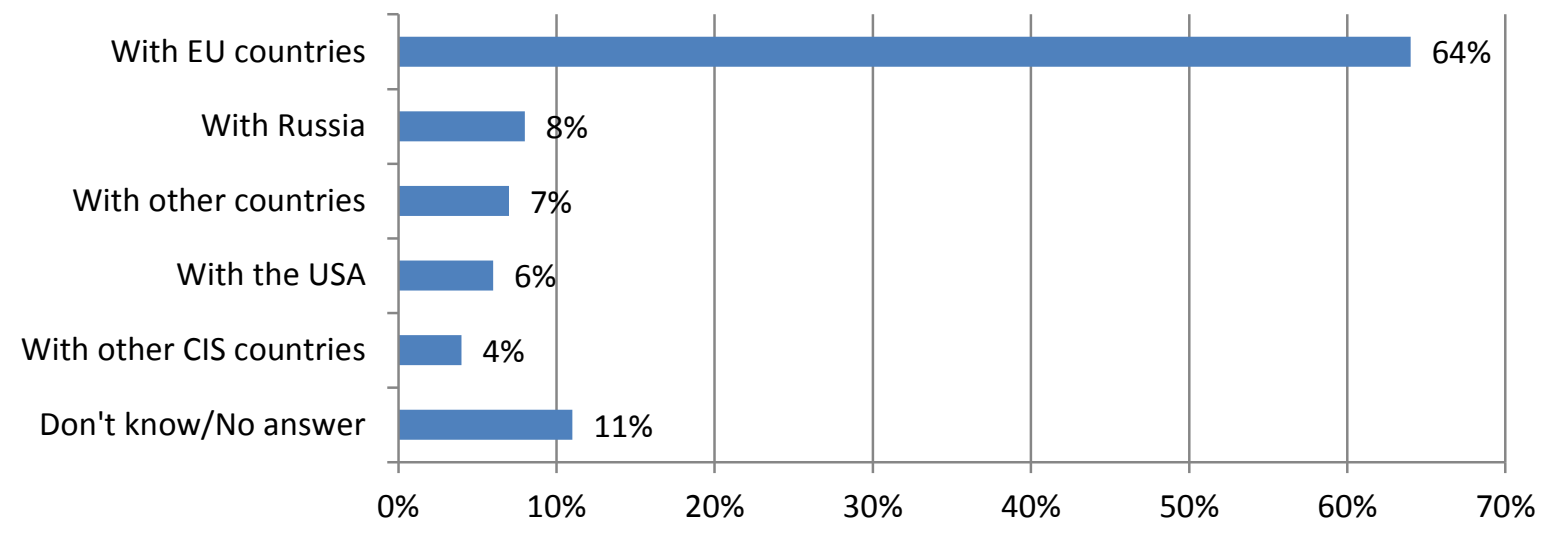

Figure 2. Priority direction of Ukraine's foreign policy. Adapted from: Public attitude towards Ukraine's integration into the EU. Results of a nationwide sociological survey, 2019 year.

From the integration into the EU, Ukrainians primarily expect to expand the space of their own capabilities and the country's internal development in accordance with modern world trends. Among the respondents, the main arguments for Ukraine's joining the EU were better opportunities for travel and acquaintances (86\%), better education, employment and medicine (84\%), the development of the state using the latest technologies (83\%), reforming state bodies, high standard of living, equal rights and opportunities for women and men (81\%), better protection of human and minority rights (80\%), better military defense of Ukraine (79\%), faster economic development (76\%), faster democratization of the society $(75 \%)$ and restoration of the territorial integrity of Ukraine (74\%). Thus, Ukrainians associate securing, in the first place, the so-called "social package" and the possibility of increasing the level of well-being. After all, Europe through the eyes of the Ukrainian (according to the analysis of the state of implementation of the basic principles of development) looks rich (93\%), with high social standards of living (93\%) and pure nature (ecology) (92\%).

First of all, Ukrainians associate the entry into the EU with ensuring the so-called "social package" and the possibility of increasing the level of well-being. In fact, in the minds of Ukrainians (according to an analysis of the state of implementation of the basic principles of development), Europe appears to be rich (93\%), with high social standards of living (93\%) and pure nature (ecology) (92\%).

On the other hand, the main arguments against Ukraine's accession to the EU were the following: inhibition of the development of political and economic relations with Russia (37\%), mass outflow of the population from the country (35\%), Ukraine's dependence on developed European countries (34\%), increased risk of economic exploitation of the country $(31 \%)$, the possibility of a massive influx of refugees from the Middle East to Ukraine $(30 \%)$, an increased risk of continued Russian aggression against Ukraine (29\%), a threat to Ukrainian national identity (26\%). Thus, today every third Ukrainian is worried about the issue of relations with Russia and they, thinking about the European prospects of Ukraine, mentally look back at the "northern neighbour". 
The space of Euro-integration challenges and obstacles for the residents of Ukraine is formed in the field of high state policy and moved beyond the limits of personal consciousness, which, as it were, hints: "This is not the business of an ordinary Ukrainian, and let this issue be first resolved in the higher groups of society." This means that Ukrainians primarily expect social benefits for themselves from European integration, but the process is assigned to individuals and officials. This means that Ukrainians primarily expect social benefits for themselves from the European integration, but the process is assigned to government individuals and officials.

Among the main internal obstacles that impede Ukraine's European integration, residents distinguish the following: a high level of corruption in the country $(57 \%)$, problems in the Donbass (41\%), inefficiency of the public administration system (33\%), socio-economic problems and instability (22\%), lack of consensus in the European integration policy (18\%).

The given indicators show that for Ukrainians the most acute internal problem for European integration is corruption. More than $70 \%$ of Ukrainians are convinced that the level of corruption in the country has not decreased, and the government does not want to expose corruptionists. The level of corruption in Ukraine is high primarily because people started to talk about corrupt practice, trying to fight it. Most bribe takers, according to Ukrainians, are among government employees (65\%), people's deputies (64\%), tax officials $(62 \%)$, judges (61\%), police officers (54\%). The last place in the ranking was occupied by representatives of religion (32\%) (Zubkova, 2017, p. 46).

Ukraine took $130^{\text {th }}$ place out of 168 positions in the global Corruption Perceptions Index, published in Transparency International (Deutsche Welle, 2017). At the end of 2016, the country received 27 points out of 100 possible, being in the ranking at the same level with Iran, Cameroon, Nepal, Nicaragua and Paraguay. At the same time, Russia took $119^{\text {th }}$ place in the ranking, Belarus $-107^{\text {th }}$, Poland $-30^{\text {th }}$, Georgia $-48^{\text {th }}$, and Germany $-10^{\text {th }}$.

The issue of effective prevention and combating corruption is one of the most important problems that the modern Ukrainian state is trying to solve. The relevance of this issue is caused by the fact that corruption provokes and aggravates social crisis phenomena, undermines the image of Ukraine on the world stage, negatively affects micro and macroeconomic processes, prevents the establishment of a constructive dialogue between the government and the public, destroys the foundations of building a legal state and civil society.

The external challenges of Ukraine's European integration process include: possible disappointment from European partners (47\%), change and redistribution of the balance of power in the world (24\%), lack of effective international guarantees of Ukraine's security (23\%), EU's unwillingness to provide Ukraine with a membership perspective ( $22 \%$ ), the lack of a single position in the EU regarding Ukraine's European prospects (21\%), the lack of a full understanding of the situation in Ukraine in the EU (20\%), Russia's energy pressure on EU member states (20\%). 
The next main tasks (Figure 3) in the European integration process, Ukrainians consider the full implementation of anti-corruption measures (69\%), ending the Donbass war and restoring territorial integrity (48\%), completing judicial reform (37\%), bringing Ukrainian legislation closer to EU standards (28\%) and preparations for the full membership of Ukraine in the EU (28\%), as well as negotiations on expanding the free trade zone with the EU (24\%):

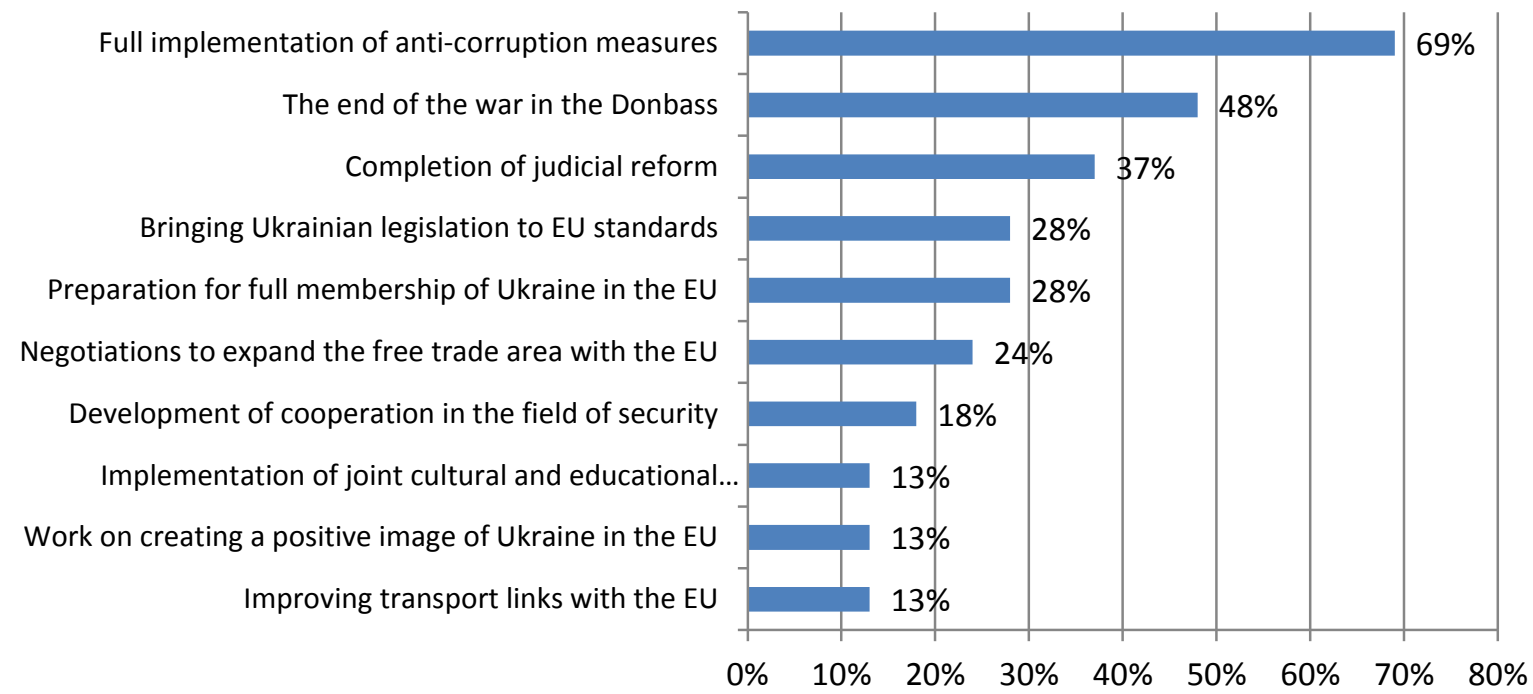

Figure 3. Next steps for European integration of Ukraine. Adapted from: Public attitude towards Ukraine's integration into the EU. Results of a nationwide sociological survey, 2019 year.

The results of a survey of Ukrainians on the level of coordination of the introduction of reforms in the country show that the majority of the population $(73 \%)$ believes that Ukraine needs them. Although in reality, the state has a difficulty in introducing innovations, a fairly wide criticism and misunderstanding on the part of ordinary Ukrainian.

Some experts (Sidenko, 2018) note that the process of Ukrainian reforms has revealed great problems in terms of their real social effect. These problems are obvious, especially if we compare the assessments of results by Ukrainian reformers and their European partners with the assessments of Ukrainian society (table 1). The above data convince us that despite the implementation of reforms that are considered successful, the majority of the population of Ukraine either does not know anything about the reform, or does not feel any changes due to its implementation.

Ukrainian reforms are extremely ambiguous in terms of their real results. On the one hand, it is hardly possible to deny the fact that the institutional changes that have occurred in Ukraine over the past five years are most widespread in their scope and impact on society. But on the other hand, it should be understood that reforms are not carried out for the sake of institutional changes themselves and adjustment to a specific template - even if it is set by a "centre", which is at a significantly higher level of institutional maturity. The main criterion for any reforms is the disclosure of the potential for the development of society, the creation of new resources for it and, in the end, the achievement of tangible positive results. 
Table 1.

Comparison of assessments of Ukrainian reforms: official Ukrainian-European position and opinion of Ukrainian society

\begin{tabular}{|l|c|c|c|c|}
\hline \multirow{2}{*}{$\begin{array}{c}\text { Joint statement of the 20th } \\
\text { Ukraine-EU Summit } \\
\text { (July 9, 2018) }\end{array}$} & \multicolumn{3}{|c|}{$\begin{array}{c}\text { Public opinion, } \\
\text { \% of the total number of respondents }\end{array}$} \\
\cline { 2 - 5 } $\begin{array}{c}\text { Areas or directions of reforms } \\
\text { that are considered successful }\end{array}$ & $\begin{array}{c}\text { "I don't know } \\
\text { anything about } \\
\text { this reform" }\end{array}$ & \multicolumn{2}{|c|}{ The impact of reforms on the personal situation of } \\
\cline { 2 - 5 } positive & 10 & 33 & 74 & negative \\
\hline Health care reform & 77 & 6 & 58 & 20 \\
\hline $\begin{array}{l}\text { Public administration reform } \\
\text { Decentralization of public }\end{array}$ & 36 & 23 & 76 & 20 \\
\hline $\begin{array}{l}\text { New legislation on privatization } \\
\text { and management of state-owned } \\
\text { enterprises }\end{array}$ & 31 & 3 & 63 & 19 \\
\hline $\begin{array}{l}\text { Improving National Security } \\
\text { Laws }\end{array}$ & 46 & 17 & 61 & 32 \\
\hline $\begin{array}{l}\text { Energy Reform and Adoption of } \\
\text { an Energy Strategy until 2035 }\end{array}$ & 41 & 6 & & 20 \\
\hline
\end{tabular}

Adapted from: "Reformatting The European Integration Process: Opportunities and Risks for the Ukraine-EU Association" by V.Sidenko. 2018 by Zapovit.

The indicators of economic development can determine the equality of the level of economic development, the complementarity of economies, the presence of political issues regarding unification. Equality of economic development can be estimated using macroeconomic indicators: GDP per capita, GDP growth rate, its sectoral structure, inflation and unemployment levels, labour productivity and wages etc. They should not have significant differences, so the most effective is the integration of economically developed countries. Let's compare these indicators for several EU countries (Table 2).

Table 2.

Macroeconomic indicators of the EU and Ukraine

\begin{tabular}{|l|c|c|c|c|}
\hline \multicolumn{1}{|c|}{ Country } & $\begin{array}{c}\text { GDP per capita, } \\
\text { USD }\end{array}$ & $\begin{array}{c}\text { Consumer price } \\
\text { inflation, } \%\end{array}$ & $\begin{array}{c}\text { Average salary, } \\
\text { USD }\end{array}$ & $\begin{array}{c}\text { Unemployment } \\
\text { rate, } \%\end{array}$ \\
\hline Ukraine & 2905,9 & 13,9 & 192 & 8,8 \\
\hline Poland & 15049,0 & $-0,6$ & 802 & 5,3 \\
\hline Germany & 45551,5 & 0,5 & 3478 & 4,2 \\
\hline Greece & 22736,5 & $-0,8$ & 1631 & 23,0 \\
\hline France & 42013,3 & 0,2 & 3374 & 9,8 \\
\hline Lithuania & 15872,7 & 0,9 & 914 & 9,2 \\
\hline
\end{tabular}

Adapted from: Pysin and Echina, 2017.

These data reflect a significant gap between Ukraine and the EU in terms of GDP per capita, inflation level and average wages.

Ukraine continues to lose positions in the global ranking of countries in terms of economic competitiveness. So, according to the Global Competitiveness Index published by the World Economic Forum 2017-2018, Ukraine took the $81^{\text {th }}$ place among 137 countries of the world (Table 3). 
Table 3.

Positions of Ukraine and some countries of the world according to the Global Competitiveness Index

\begin{tabular}{|l|c|c|c|c|c|}
\hline Countries & $\begin{array}{c}\mathbf{2 0 1 3 - 2 0 1 4} \\
\text { (place of 148 } \\
\text { countries) }\end{array}$ & $\begin{array}{c}\mathbf{2 0 1 4 - 2 0 1 5} \\
\text { (place of 144 } \\
\text { countries) }\end{array}$ & $\begin{array}{c}\mathbf{2 0 1 5 - 2 0 1 6} \\
\text { (place of 140 } \\
\text { countries) }\end{array}$ & $\begin{array}{c}\text { 2016-2017 } \\
\text { (place of 148 } \\
\text { countries) }\end{array}$ & $\begin{array}{c}\mathbf{2 0 1 7 - 2 0 1 8} \\
\text { (place of 137 } \\
\text { countries) }\end{array}$ \\
\hline Ukraine & 84 & 76 & 79 & 85 & 81 \\
\hline Georgia & 72 & 69 & 66 & 59 & 67 \\
\hline Turkey & 44 & 45 & 51 & 55 & 53 \\
\hline Poland & 42 & 43 & 41 & 36 & 39
\end{tabular}

Adapted from: Ukraine's position in the rating of the world by Global Competitiveness Index 2017-2018.

Despite minor improvements, in 2018 Ukraine still holds the worst position in the world in assessing the strength of banks $\left(130^{\text {th }}\right.$ place $)$, in regulating stock exchanges $\left(134^{\text {th }}\right)$, in terms of road quality $\left(130^{\text {th }}\right)$, in inflationary changes and in the country's ability to retain talented people $\left(129^{\text {th }}\right)$, protection of property rights $\left(128^{\text {th }}\right.$ place $)$.

In this aspect, the analysis of the Inclusive Growth and Development Index (IDI) developed by the World Economic Forum is also noteworthy. The need to introduce a new index is justified by the fact that economic policy priorities should be reoriented to a more effective counteraction to the insecurity and inequality that accompany technological changes and globalization. It is steady, comprehensive progress, accompanied by an increase in the income of the population along with the expansion of its economic opportunities, an increase in the level of security and quality of life, which should be recognized by politicians as the main goal of economic development, and not at all the growth of GDP.

According to this indicator, among the developed countries, Norway, Luxembourg and Switzerland were in the top three, and Greece was in the last place. Ukraine takes $78^{\text {th }}$ place among developing countries (its neighbours in the ranking are Honduras, Laos, Armenia) (Bobukh, and Shchegel, 2018, p. 58).

In 2017, according to the data of the specialists of the Swiss bank "Credit Suisse" (Global Wealth Report, 2017) Ukraine remained one of the poorest countries in Europe with an average well-being of an average adult of 1224 USD (in 2015 this figure was 1437 USD, i.e. decreased by 213 USD). For comparison, this indicator of Zimbabwe was 3640 USD, respectively.

The above presented data indicate extremely low volumes of internal resources of the domestic economy, and an even lower level of equity in their distribution, which requires the introduction of progressive world-wide approaches to the formation of a new quality of economic growth in Ukraine.

At the beginning of 2019, Vice President of World Bank for Europe and Central Asia Cyril Muller (It will take Ukraine 50 years..., 2019) noted that without reform and having a current GDP growth rate, Ukraine needs 50 years to reach the level of development of Poland, and of Germany - a century. 
The World Bank representatives also state that the economic growth rate in Ukraine remains too low to reduce poverty and achieve income indicators of neighbouring European countries. So, after a 16 percent cumulative contraction in the economy in 2014-2015, economic growth resumed to the level of $2.4 \%$ in $2016-2017$ and $3.3 \%$ in 2018. According to experts, in terms of GDP per capita, Ukraine remains one of the poorest countries in the region, that is, our country remains at the level of Moldova, Armenia and Georgia.

According to Muller, in Ukraine there is a significant concentration of capital in the hands of a small group of the population. So, the three richest Ukrainians possess $6 \%$ of the country's GDP. This is almost three times more than in Poland. The ratio of incomes of the richest people to GDP has not changed much since 2007. This limited access to economic opportunities that could fully unlock the potential of human capital. Experts note that the largest factors restraining the economic development of Ukraine are too high level of credits received, heavy reliance on world markets for raw materials, and late in the day start of reforms. The priority reforms in Ukraine, according to representatives of the World Bank, should be tax reform, improved logistics and the lifting of the moratorium on land sales. In addition, it is important to carry out judicial reform and reform of the Antimonopoly Committee.

This situation hinders the integration processes, and a great difference between the level of wages in Ukraine and the EU countries, as well as geographical proximity contributes to active migration processes.

According to the State Statistics of Ukraine, the main countries of destination of Ukrainian migrant workers are neighbouring countries - Russia, Poland, the Czech Republic, Hungary, as well as countries of Southern Europe (Italy, Spain, Portugal). Comparison of the results of 2008, 2012 and 2017 shows that gradually the distribution of migrants by destination countries was changing: the share of Russia was declining, and European countries, primarily Poland, was growing (Figure 4):

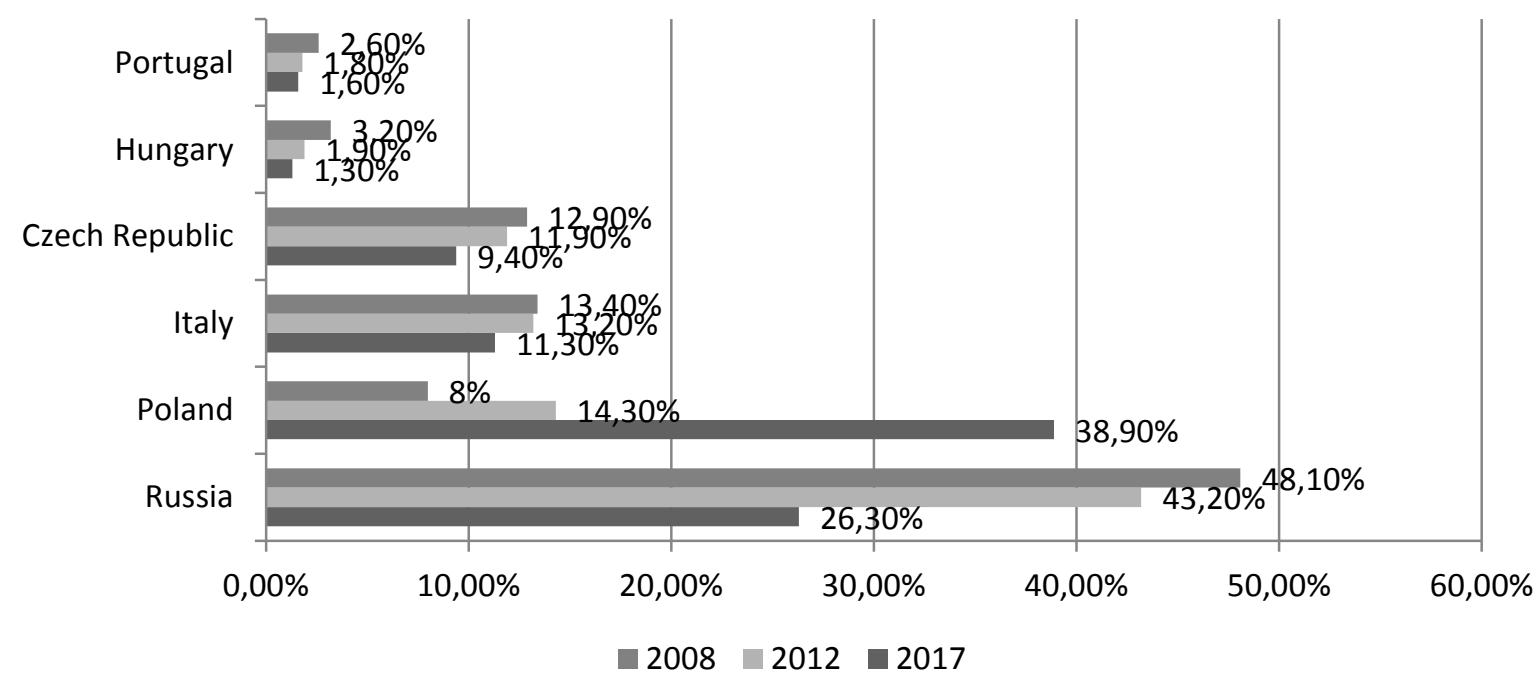

Figure 4. Destination countries of Ukrainian labour migrants according to a population survey in 2008, 2012 and 2017; Adapted from: "Labor migration of Ukrainian citizens abroad: challenges and ways to respond" by O.A. Malynovska. 
It is Poland today that is the main destination country for labour migrants from Ukraine, which is caused by the needs of the country's labour market, favourable for temporary (up to 6 months in a year) employment of foreigners by legislation, territorial and cultural proximity.

Data of destination countries indicate that the number of Ukrainians living there on a permanent basis is growing steadily. So, according to Eurostat, the number of Ukrainian citizens who received the status of a long-term migrant in the EU, which ensures full rights of a permanent resident and is granted after five years of legal residence, is growing steadily. Over the past 10 years, it has increased almost tenfold (Figure 5).

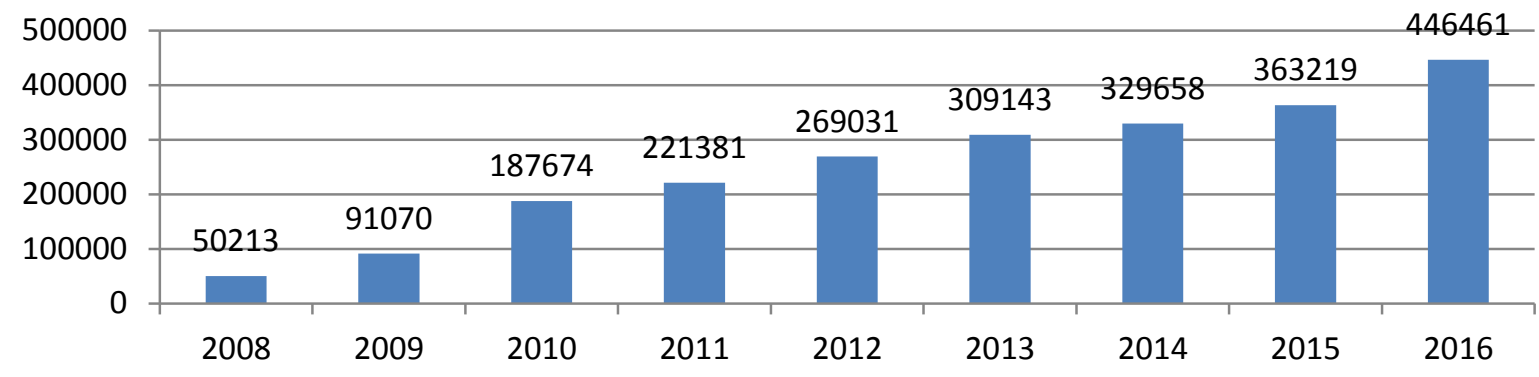

Figure 5. Citizens of Ukraine who had a residence permit in the EU as long-term migrants (at the end of the year), number of people; Adapted from: "Labor migration of Ukrainian citizens abroad: challenges and ways to respond" by O.A. Malynovska.

Only during 2016, 24100 Ukrainians received citizenship of the EU countries. They And this is without taking into account migrants who have already managed to acquire citizenship of the host countries. They took first place among naturalized foreigners in the Czech Republic, Poland and Romania. And if in Romania it can be assumed that we are talking about Ukrainians from Bukovyna territory, who have the right to Romanian citizenship, although they do not migrate to Romania, then in the case of the Czech Republic and Poland, acquiring citizenship is possible only for immigrants. Given the unfavourable demographic trends, the gradual transformation of a temporary labour migration into resettlement is for Ukraine the most serious danger caused by migration.

A serious challenge for Ukraine is caused by the fact that in recent years the number of citizens working abroad without proper permits has increased. According to State Statistics survey provided in $2008,23.2 \%$ of migrants had an unregulated legal status; according to the survey in 2012, their numbers decreased to 16.7\%. However, the 2017 survey showed that it rose again: $17.9 \%$ of the identified migrants had no legal status abroad, $5.5 \%$ worked only with a tourist visa, the legal status of $4.8 \%$ of migrants remained unclear, that in most cases means its absence.

In addition to the threats faced by illegal migrants, such situation poses a risk to the image of Ukraine and a visa-free regime with the EU. After all, there is a procedure for suspending Visa-free regime, which is launched, in particular, in the case of a sharp increase in the number of legislation violations. This is a very real threat. Moreover, in recent years, the number of Ukrainian violators of EU migration legislation has increased significantly (Table 4). 
Table 4.

TOP 10 countries in which the largest influx of illegal migrants to the EU countries is noted (number, thousand people)

\begin{tabular}{|l|c|c|c|c|c|c|c|c|c|c|c|}
\hline \multicolumn{1}{|r|}{ Years } & $\mathbf{2 0 0 8}$ & $\mathbf{2 0 0 9}$ & $\mathbf{2 0 1 0}$ & $\mathbf{2 0 1 1}$ & $\mathbf{2 0 1 2}$ & $\mathbf{2 0 1 3}$ & $\mathbf{2 0 1 4}$ & $\mathbf{2 0 1 5}$ & $\mathbf{2 0 1 6}$ & $\mathbf{2 0 1 7}$ & $\begin{array}{c}\text { Total, } \\
\mathbf{2 0 0 8 - 2 0 1 7}\end{array}$ \\
\hline $\begin{array}{l}\text { In general, } \\
\text { of which: }\end{array}$ & 583,2 & 568,5 & 508,8 & 474,7 & 439,4 & 452,2 & 672,2 & 2155 & 983,9 & 618,8 & 7456,8 \\
\hline Syria & 4,5 & 4,7 & 4,1 & 5,4 & 17,1 & 33,1 & 118,8 & 859,0 & 213,0 & 39,3 & 1299,3 \\
\hline Afghanistan & 49,9 & 50,6 & 42,1 & 46,4 & 35,7 & 26,1 & 48,5 & 409,3 & 151,8 & 35,4 & 895,9 \\
\hline Iraq & 37,4 & 23,5 & 16,8 & 12,1 & 9,3 & 6,5 & 10,3 & 185,3 & 93,0 & 36,4 & 430,6 \\
\hline Albania & 72,7 & 69,0 & 52,5 & 17,2 & 18,6 & 27,3 & 32,2 & 50,1 & 36,1 & 40,0 & 415,9 \\
\hline Morocco & 39,5 & 32,5 & 29,8 & 29,0 & 28,1 & 27,2 & 32,1 & 41,7 & 39,5 & 38,1 & 337,6 \\
\hline Pakistan & 13,2 & 15,5 & 19,5 & 33,1 & 30,3 & 27,4 & 24,0 & 81,8 & 46,5 & 33,6 & 325,2 \\
\hline Eritrea & 21,0 & 10,7 & 7,1 & 8,1 & 6,0 & 10,2 & 50,8 & 41,6 & 23,3 & 17,9 & 196,6 \\
\hline Algeria & 15,8 & 15,9 & 19,3 & 18,2 & 17,7 & 15,4 & 15,4 & 19,4 & 23,8 & 25,0 & 185,9 \\
\hline Ukraine & $\mathbf{1 2 , 8}$ & $\mathbf{1 1 , 5}$ & $\mathbf{1 1 , 2}$ & $\mathbf{1 2 , 8}$ & $\mathbf{1 2 , 9}$ & $\mathbf{1 2 , 7}$ & $\mathbf{1 6 , 9}$ & $\mathbf{2 3 , 9}$ & $\mathbf{2 9 , 8}$ & $\mathbf{3 3 , 8}$ & $\mathbf{1 7 8 , 3}$ \\
\hline Nigeria & 16,4 & 16,4 & 16,9 & 14,1 & 12,1 & 14,4 & 16,4 & 20,4 & 20,5 & 19,4 & 167,1 \\
\hline
\end{tabular}

Adapted from: "Reformatting The European Integration Process: Opportunities and Risks for the Ukraine-EU Association" by V.Sidenko. 2018 by Zapovit.

During 2014-2017, there was a change in the main direction of labour migration of Ukrainian citizens: due to the reduction of migrants in the Russian Federation, the number of labour migrants working in the EU has sharply increased. The reason for this change was not only the aggressive actions of the Russian Federation against Ukraine, but also the relatively better working conditions and salaries in European countries.

The growth in labour migration, due to the crisis in the Ukrainian economy and the slow implementation of reforms, has led to a shortage of skilled workers in a number of specialties. Such a tendency has acquired features that define it as one of the threats to the national security of the state. The long-term orientation of the Ukrainian business community to success in the competition by means of paying relatively low salaries to the workers has led to the formation of a stable idea in a significant part of working-age citizens about the impossibility of successful self-realization on the territory of Ukraine. Signs of a crisis in the Ukrainian labour market have become noticeable. Against the backdrop of economic problems, the growth in the accumulation of funds of Ukrainian migrant workers has become significant. This tendency looks rather threatening in light of the fact that for some regions of Ukraine (mainly western), the volume of investments initiated by labour migrants significantly prevailed over foreign direct ones. Certain tendencies in external labour migration over time may become a problem that Ukraine will not be able to successfully overcome, while remaining a low-wage country, which is characterized by an increase in the number of external labour migrants (including skilled workers). This can significantly complicate the introduction of innovative technologies in Ukraine, the implementation of the latest state programs for the development of industry and agriculture. 


\section{Discussion}

The results of the development of the Ukrainian economy, caused by its lack of reform, negatively affect the European integration processes. Therefore, further effective cooperation between Ukraine and the EU is almost impossible without deep socio-economic reforms and radical institutional reforms in Ukraine.

The movement from the command and administrative to the modern economy for its successful implementation must take into account world experience and have a certain logic, which is to form the basic elements of a market system on market principles.

For its successful implementation, the movement from a command-administrative to a modern economy should take into account world experience and have a certain logic, which consists in forming the basic elements of a market system on market principles.

According to the first president of the European Council, Herman Van Rompuy, Ukraine and the EU have signed "the most modern agreement that the European Union has ever concluded" aimed at "the gradual integration of Ukraine into the EU internal market." Therefore, the complexity of the concluded Association Agreement between Ukraine and the EU provides serious challenges for its effective implementation, both from the point of view of implementation policy, and in the context of creating and providing an appropriate mechanism for coordinating the implementation of the Agreement.

Based on the results of the fulfillment of the tasks planned for 2018, the agreement was implemented by 52\% (Association agreement implementation report 2018, 2019). The greatest progress was achieved in such areas as entrepreneurship (89\%), agriculture $(86 \%)$, reduction of technical barriers to trade (70\%), social policy and labour relations $(70 \%)$. The least successful is the fulfillment of obligations in such areas as education, training and youth (13\%), transport, transport infrastructure, postal and courier services (15\%), public procurement $(16 \%)$, the environment and civil protection (22\%).

Ukraine remains at a high level of accession to statements and declarations made on behalf of the EU, that testifies the common views and approaches regarding settlement and proper response to regional and global challenges. In 2018, Ukraine joined 492 of 588 EU statements and declarations.

The implementation of the Association Agreement was positively assessed at the 20th Ukraine-EU Summit, which took place on July 9, 2018. At the highest level of political dialogue, four priority areas of cooperation were identified to strengthen political association and economic integration of the parties in the field of digital market, customs policy, energy, and also justice, freedom and security.

The role of the EU related to the financial support for the implementation of reforms in Ukraine is significant. In 2018, Ukraine and the EU signed relevant agreements to attract the fourth macro-financial assistance program from the EU with a budget of 1 billion euro. 
Fulfillment of the first package of obligations of the Ukrainian side made it possible to attract the first tranche in the amount of 500 million euro. In addition, in the same year, the EU renewed its programmatic approach to setting medium-term aid priorities by approving a new Single Support Framework for 2018-2020. This program identifies four key sectors related to the general directions of reforms in Ukraine, for which EU assistance will be provided:

Sector 1 - strengthhening institutions and good governance, including in the area of the rule of law and security;

Sector 2 - economic development and development of market opportunities, including the development of the private sector and improving the business climate;

Sector 3 - improving communications, energy efficiency, protecting the environment and mitigating climate change;

Sector 4 - mobility and contact between people, including the implementation of more effective social policies.

The total amount of EU assistance, which will be provided on a "more for more" basis, depending on the progress of the Ukrainian side in implementing the relevant reforms during 2018-2020, provides from 430 to 530 million euro.

It should also be noted that the generally accepted rule - "reforms require money" also applies to the processes of transformation of European integration and EU mechanisms. Even a way out of this process, as evidenced by reports from the negotiation process of the UK and the EU, is associated with large financial costs. This means that the EU will face the problem of concentration of resources aimed at solving key issues of development and transformation. And with rather limited resources of the general budget, the EU will look for ways to save budget expenses. In this context, interest in countries that are not able to be a real partner and make their contribution to solving pan-European problems may be lost. For the EU, countries that constantly need external assistance (especially financial) are unlikely to be interested. Ukraine "has every chance" to get into this group of countries due to its inability to effectively develop and move out from the list of the poorest countries in Europe (Sidenko, 2018, pp. 111-116).

For Ukraine, the EU space fragmentation scenario also contains risks of diminishing political support on key issues for the country. Thus, fragmentation of the sphere of foreign and security policies, some of which are already visible in the policies of individual EU member states (although they are not very expressive so far, with the exception of Hungary, which pursues a policy of blocking Ukraine's cooperation with the EU and NATO) can lead to a real ending the policy of sanctions against Russia and moving away from the orientation of policies aimed at European values towards a policy of pragmatic pursuit of material interests.

The problem of the possible destruction of the EU common migration policy, which results in the direct refusal of Hungary and Austria to participate in the new UN global treaty on migration regulation, is no less important. Moreover, taking into account the fact of nonparticipation of the USA in this treaty, it is possible that some other EU countries can go such 
a way. For Ukraine, such a prospect carries a double risk. Firstly, the emergence of gaps in the unified migration policy will certainly complicate the general regulation of migration processes in Europe. Ukraine in this case may turn into a leading zone of illegal migration. Secondly, mass illegal migration is undoubtedly a time bomb laid down under the Schengen mechanisms for the free movement of people. Failure to find an effective solution to this problem will sooner or later cast doubt on the existence of Schengen in its current form. And in this case, one of the largest achievements of Ukraine in the field of its European integration policy will be called into question.

It seems quite fair the opinion of some experts (Sidenko, 2018, p. 109) that the currently prevailing style of "pro-European" thinking in Ukraine is based on unsystematic, rather simplified emotional ideas about European integration and is often the result of elementary ignorance of what the European integration mechanisms really are. It contains much more slogans and ideological rhetoric than real ideas about possible effective algorithms for entering the European integration space - and such state of things, from a political point of view, is extremely dangerous. Unfortunately, Ukraine lacks fruitful professional discussions and fundamental scientific research on key issues of European integration; there is much more simplified propaganda. This situation should be changed if the country expects the success of its European integration strategy.

Ukraine should carry out in-depth professional studies and hold professional discussions on issues that will be on the agenda of the EU and, accordingly, adjust its program of action in the field of European integration. Most likely, a more precise definition of priorities will be necessary - it is possible that with a certain withdrawal of certain non-priority measures and the concentration of efforts and resources on ensuring a significant increase in the effectiveness of policies in priority areas. It should be assumed that it is not the mechanical transfer of European institutions, rules, norms etc. to the Ukrainian field (that's what Ukrainian European integrators are doing today), but the creation of conditions for a progressive increase in the level of civilization of socio-economic and political processes within Ukraine that should become the dominant philosophy of the country's strategic development and that is impossible without following imperatives rooted in national culture. A country modernized on this basis has a much greater chance of becoming a part of Europe and developing diverse relations with European countries in various fields.

\section{Summary}

Thus, the analysis showed the desire of the Ukrainian people to become part of the EU. However, such an entry means for the applicant country not only a formal change in status. The European choice of Ukraine is a way of approaching the standards of democracy, civil 
society, the rule of law and ensuring the rights and freedoms of human and citizen. Successful integration of Ukraine with the EU is possible only if the Copenhagen criteria (political, economic and membership criteria) are met. The country needs to make many transformations in accordance with the established requirements, primarily on democracy and the welfare of the population. At the present stage of development of Ukraine, it lags significantly behind the EU countries in terms of economic development and is characterized by low competitiveness, high corruption, significant external labor migration, Ukrainian, lack of understanding on the part of the population of the need for changes and reforms implemented in the country. The presence of these problems in Ukraine indicates a significant discrepancy with the Copenhagen criteria and postpones its ability to join the EU for the long term.

In the modern world of global transformational changes, Ukraine's awareness of itself as an integral part of modern Europe and a component of European integration processes is an urgent issue. The task of integrating Ukraine into the European political and economic space has been repeatedly proclaimed as a priority vector for joining the world economy, and the development of comprehensive cooperation with the European Union has been put on the line of the day. Ukrainian society primarily expects European integration to improve social standards and leisure activities. But the success of any European integration policy does not lie in statements and declarations about the European choice, but in the banal adherence to the principles and objectives of this policy.

Ukraine needs to form its own "action plan" so that in Europe it is perceived as a reliable partner. The time and prospects of Ukrainian European integration will depend on whether Ukraine can formulate and adequately realize its national interests, taking into account the interests of the parties involved in European construction and influencing it. And also on how much it will be internally prepared for this process. After all, it is precisely the internal problems in the country (extremely low economic development, a high level of corruption, mass migration of the able-bodied population abroad) that slow down and complicate Ukraine's path to European integration.

For Ukraine, European integration is the way to modernize the economy, overcome technological backwardness, attract foreign investment and the latest technology, create new jobs, increase the competitiveness of domestic producers, enter global markets, primarily the EU market. The European choice of Ukraine opens up new prospects for cooperation with developed countries of the continent and is the best way to realize national interests. 


\section{References}

1. Archick, K. European Union: Current Challenges and Future Prospects. Retrieved from: https://fas.org/sgp/crs/row/R44249.pdf, 16.07.19.

2. Association agreement implementation report 2018. Available online: https://eu-ua.org/ sites/default/files/inline/files/association-agreement-implementation-report-2018.pdf, 06.08.19.

3. Bassot, E. Ten issues to watch in 2018. Retrieved from: http://www.europarl.europa.eu/ RegData/etudes/IDAN/2018/614650/EPRS_IDA(2018)614650_EN.pdf, 18.07.19.

4. Berend, I. (2017). The Contemporary Crisis of the European Union: Prospects for the Future. New York: Routledge.

5. Bobukh, I.M., and Shchegel, S.M. (2018) Strategic environments of economic growth in Ukraine: inclusiveness as a key priority. Bulletin of the National Academy of Sciences of Ukraine, 7, 55-70. doi: https://doi.org/10.15407/visn2018.07.055.

6. Chalmers, D., Jachtenfuchs, M., and Joerges, C. (2016). The end of the Eurocrats' dream: adjusting to European diversity. New York: Cambridge University Press.

7. Czaputowicz, J. (2016). Globalna strategia UE - koniec Unii Europejskiej jako potęgi normatywnej? (Global Strategy for the EU - the end of the EU as a Normative Power?) Przeglad Europejski, 4(42), 25-36.

8. de Vries, C.E. What is the future of the European Union? Retrieved from: https://blog.oup.com/2018/03/future-european-union-euroscepticism, 18.07.19.

9. Global Wealth Report 2017. Credit Suisse AG Research Institute. Available online: https://www.credit-suisse.com/corporate/en/research/research-institute/global-wealthreport.html, 02.08.19.

10. It will take Ukraine 50 years to reach Poland's current economic level - the World Bank. Available online: https://hromadske.ua/posts/ukrayini-znadobitsya-50-rokiv-dlyadosyagnennya-potochnogo-ekonomichnogo-rivnya-polshi-svitovij-bank, 02.08.19.

11. Malynovska, O.A. Labor migration of Ukrainian citizens abroad: challenges and ways to respond. Retrieved from: http://old2.niss.gov.ua/content/articles/files/Malynovskad28e1.pdf, 06.08.19.

12. Obozna, A.O., and Klimova, M.V. (2017). Problems and prospects of economic development of Ukraine under European integration Eastern Europe: Economy, Business, Management, 3. Retrieved from: http://www.easterneurope-ebm.in.ua/journal/8_2017/07. pdf, 18.07.19.

13. Osipova, L. (2015). Ukrainian economy reformation within EU integration. Herald of Kyiv National University of Trade and Economics. Scientific Journal, 5, 39-53.

14. Public attitude towards Ukraine's integration into the EU. Results of a nationwide sociological survey. 2019 year. Available online: http://crst.com.ua, 22.07.19. 
15. Pysin, V.M., and Echina, L.V. (2017). Feutures of Ukraine's integration into the EU: the challenge of time. Economics and Society, 13. Retrieved from: http://www.economyandsociety.in.ua/journal/13_ukr/13_2017.pdf, 18.07.19.

16. Shynkar, V.A., Roshko, S.M., and Yatsko, G.V. (2017). Formation of Ukraine European integration. Scientific Bulletin of Uzhgorod National University, 12, 173-176.

17. Sidenko, V. (2018). Reformatting The European Integration Process: Opportunities and Risks for the Ukraine-EU Association. Kyiv: Zapovit.

18. Soros, G., and Schmitz, G. (2016). The European Union is on the Verge of Collapse. The New York Review of Books, 63, 2. Retrieved from: http://www.nybooks.com/ articles/2016/02/11/europe-verge-collapse-interview, 16.07.19.

19. Stepanenko, N.O., and Stepanenko, V.O. (2018). Ukraine's integration into the European Union: advantages and disadvantages. The Herald of transport economy and industry, 61, 62-67.

20. Stiglitz, J.E. (2016). How a Common Currency Threatens the Future of Europe. New YorkLondon: W.W. Norton \& Company.

21. Transparency International: Ukrainians are extremely dissatisfied with the level of the fight against corruption. Available online: https://www.dw.com/uk/transparency-international, 26.07.19.

22. Ukraine's position in the rating of the world by Global Competitiveness Index 2017-2018. Available online: http://edclub.com.ua/analityka/pozyciya-ukrayiny-v-reytyngu-krayinsvitu-za-indeksom-globalnoyi-konkurentospromozhnosti-2, 06.08.19.

23. Zięba, R. (2017). Próby ożywienia polityki bezpieczeństwa i obrony Unii Europejskiej (Attempts to revive the European Union's security and defence policy). Krakowskie Studia Międzynarodowe. Czesść 1: Zagrożenia, wyzwania i przyszłość polityki bezpieczeństwa Unii Europejskiej $w$ dobie kryzysu, 1, 35-52.

24. Zubkova, L.O. (2017). The current state and problems of preventing corruption in Ukraine. Scientific Bulletin of the National Academy of Internal Affairs, 3, 34-44.

25. Żukrowska, K. (2017). Rozwój Unii Europejskiej do 2020 roku a nowe wyzwania globalizacji i konkurencji międzynarodowej z uwzględnieniem roli, miejsca i interesów Polski (The EU Development till 2020 and New Challenges in Area of Globalization and International Competition Including Role, Position and Interest of Poland). Krakowskie Studia Międzynarodowe. Część 1: Zagrożenia, wyzwania i przyszłość polityki bezpieczeństwa Unii Europejskiej w dobie kryzysu, 1, 17-33. 